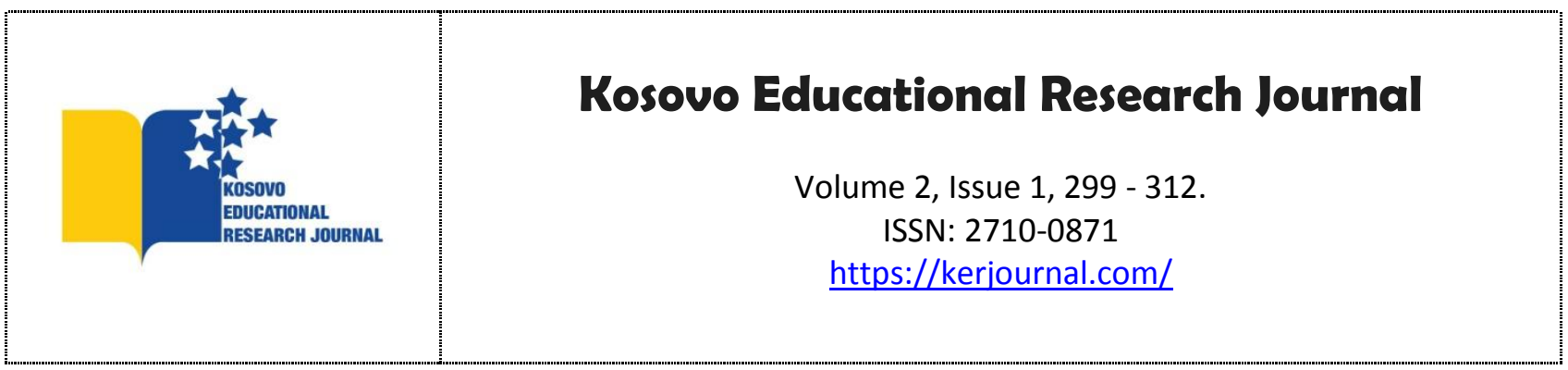

\title{
Okul Öncesi Çocukların Eğitiminde Oyunun Önemi ve Okul Öncesi Öğretmen Adaylarının Görüşleri
}

Derya Brlajolli

\begin{abstract}
Özet: Çocukluk yıllarında oyunun çocuklar için ne kadar önemli olduğu bariz bir gerçektir. Özellikle okul öncesinde çocuğun eğitim hayatına hazırlandığı bu dönemde oyunu bir öğretme yöntemi olarak kullanmak çocukların öğretilmek istenen bilgiyi kalıcı bir şekilde öğrenmesine yol açmaktadır. Çalışmamızın amacı da okul öncesi öğretmen adaylarının oyunun önemi hakkında ki görüşleri ve tutumlarını anlamak ve aynı zamanda öğretmen adaylarımızı ilerde ki mesleklerinde oyunu yöntem olarak kullanmaları doğrultusunda bilinçlendirmektir. Araştırmada nitel araştırma yöntemlerinden görüşme tekniği kullanılmıştır. Araştırmamıza katılan okul öncesi öğretmenliği 3. ve 4. sınıf öğrencilerinden elde edilen bulgular oyunu bir öğretme yöntemi olarak kullandığımız takdirde çocuğun aktif öğrenmesini ve öğrenirken eğlenmesini ayrıca bu yöntemin çocukların zihinsel, sosyal, duygusal gelişim alanlarına olumlu yönde etkisi olduğu yönündedir.
\end{abstract}

Anahtar kelimeler; okul öncesi eğitimi, çocuk, oyun

To cite this article: Brlajolli, D. (2021). Okul Öncesi Çocukların Eğitiminde Oyunun Önemi ve Okul Öncesi Öğretmen Adaylarının Görüşleri. Kosovo Educational Research Journal, 2(1), 55-61.

\section{Giriş}

Oyun, pek çok araştırmacı tarafından derinlemesine incelenerek, farklı ve birbirini tamamlayan pek çok tanımla karşımıza çıkmaktadır. Tüm bu tanımların temelinde John Huizinga (1955) ve arkasından Rubin, Fein ve Vandenberg (1983)' in çalışmaları yer almaktadır. Bu araştırmacılar çalışmalarında oyunu gözlenebilen davranışlar ve kaynak olarak görmektedir (akt. Sluss, 2005). Fromberg (1992) oyunun düşünme ve sembolik, anlamlı, aktif, zevk veren, gönüllü, kurala ve olaylara dayanan bir etkinlikle karakterize edildiğini belirtmektedir (Fleer, 2009). Froebel (1902) ise; genel olarak erken çocukluk eğitiminin önemine dikkat çekerek, oyunun boş bir zaman dilimi olmadığını, oldukça ciddi ve derin bir 
öneme sahip olduğunu, çocukluk dönemindeki oyunun daha sonraki yaşamın tohumlarını attığını belirtmektedir. Çocukların doğal gelişimlerini teşvik etmek için, Frobel oyunu anaokulu programının merkezindeki bileşen olarak ele alarak, iş ve oyun şeklinde ikiye ayırmaktan kaçınmış, bunun yerine oyunu çocukların işi olarak görmüştür (akt. Brosterman, 1997). Brosterman'e (1997) göre oyun anaokulundaki hedeflere ulaşabilmek için birinci derecede önemlidir ve tüm anaokulu etkinlikleri, dans, bahçe işleri, şarkı söyleme, hikâye okuma oyundur; oyun sistemin çalışmasını sağlayan, onu ileri götüren bir makine gibidir (akt. Tuğrul, B., Metin Aslan, Ö., Ertürk, H. G., \& Özen Altınkaynak, Ş. 2014).

Piaget ise oyunu çocukların gerçek hayatlarını anlamlı hale getirme ve çevredeki görevlerini öğrenme yolu olarak nitelendirmektedirler. Ayrıca çocukların bilgi edinmeleri sadece yaparak-yaşayarak gerçekleşebileceği gibi, bu durumu günlük yaşantılarında etkinliklerle veya deneylerle yapabilmeleri mümkün olacağı bir gerçektir. Oyunla ilgili yapılan tüm tanımların ortak noktası oyunun çocuğun kişisel gelişimi, deney yeri, keşif alanı, bilgi edinme ortamı, öğrenme dili ve en temel uğraşı olduğu açıklanmıştır. olmasıdır. Bu ortak noktalardan hareketle; oyun ve öğrenme arasındaki önemli bağın yetişkinler tarafından da göz ardı edilmemesi gerekmektedir. Yetişkinlerin çocuklarının oyununa verdiği değer ile çocukların öğrenmelerine verdiği değer eşdeğer sayılabilir. Oyun hem ebeveynler için hemde çocuklar için önemli olduğu kadar öğrenme ortamlarının düzenlenmesi ve öğretme yöntemi olarak kullanılabilirliği açısından öğretmenler için de çok önemlidir. Oyun yoluyla öğrenme çocuğun fikirüretmesine, araştırma, inceleme ve gözlem yapmasına, katılım göstermesine, denemeleroluşturmasına, süreci yönlendirmesine, problem çözmesine, sorumluluk almasına, esnekve yaratıcı olmasına imkan sunmaktadır (Tuğrul, 2010, Russo, 2009, Broadhead,2007).

Yapılan bir diğer çalışmada okul öncesi öğretmenliği son sınıf öğrencilerinin oyun temelli öğrenmeye bakış açılarını anlamak için yarı yapılandırılmış görüşmeler sonucunda düşünceleri alındıktan sonra oyun temelli bir etkinlik planı hazırlanmaları istenmiştir.Araştırma sonucunda ise öğretmen adaylarının oyun temelli öğrenmeye yönelik bilgi sahibi oldukları fakat uygulama sürecinde destek sağlanması gerektiği öne sürülmüş ve önerilerde bulunulmuştur (ERBİL KAYA, YALÇIN, KIMZAN, \& AVAR, 2017) .

Bir başka çalışmada ise Okul Eğitimi Anabilim Dalında eğitim alan ve "Çocukta Oyun Gelişimi” dersini alan 80 öğretmen adaylarıyla yapılan fenomenolojik bir çalışmada öğretmen adaylarına oyun ile ilgili cümlelerdeki boşlukları doldurmaları istenerek algılarını içerik analizi yöntemi kullanarak anlamaya çalışılmıştır. Elde edilen bulgularda cevapların 
çoğunluğu oyunun çocuklar için ; rahatlatıcı olması, mutluluk vermesi, hayal dünyasını yansitmas1 ve öğretme aracı olması yönündedir (TOK, 2017) .

$\mathrm{Bu}$ araştırmanın amacı ; Okul öncesi öğretmen adaylarının oyun hakkındaki görüşlerini ve tutumlarını belirlemektir. Bu araştırma ile okul öncesi öğretmenlerinin oyunun çocukların öğrenme sürecine bir yöntem olarak kullanıp kullanmamalarını ve kullandıkları takdirde bu uygulamanın çocuklara sağladığı fırsatları ortaya koymayı amaçlamıştır.

\section{YÖNTEM}

Çalışmada nitel araştırma yöntemi kullanılmıştır. Nitel araştırma; gözlem, görüşme ve doküman incelemesi gibi nitel bilgi toplama yöntemlerinin kullanıldığı, algıların ve olayların doğal ortamda gerçekçi ve bütüncül bir biçimde ortaya konmasına yönelik nitel bir sürecin izlendiği araştırma olarak tanımlanır (Yıldırım ve Şimşek, 2005). Yapılan bu araştırmada, nitel araştırma yöntemlerinden görüşme tekniği kullanılmıştır. Görüşme tekniğini yarıyapılandırılmış ve yapılandırılmamış görüşmeler olarak sınıflamak mümkündür. Yarıyapılandırılmış görüşmede sorular önceden belirlenir ve bu sorularla veriler toplanmaya çalışılır (Karasar, 1998). Bu araştırmanın verileri, görüşme türlerinden yarı-yapılandırılmış görüşme tekniği ile toplanmıştır.

\subsection{EVREN VE ÖRNEKLEM}

Çalışmanın amacı dikkatte alınarak araştırmanın çalışma evreni, Prizren Ukshin Hoti Üniversitesi öğrencilerini oluşturmaktadır. Araştırmanın örneklemi ise 2019-2020 Eğitim Öğretim yılında Prizren Ukshin Hoti Üniversitesi Türkçe okuyan okul öncesi bölümü 3. ve 4. sınıf öğrencileri oluşturmaktadır.

\section{BULGULAR}

\section{1. Öğretmenlerin Oyunu Yöntem Olarak Kullanma Konusundaki Görüşleri}

Oyun insanın doğasında var olan ve erken gelişimin dönemlerinde insanlara fiziksel, bilişsel, duygusal, sosyal gelişimlerinde önemli bir etkinliktir. Öğretmenlerin oyunu yöntem olarak kullanmalarında çocuğun gelişimi açısından çok yararlıdır. Çocuklara dersi anlatmada ve onların anlamasını en iyi şekilde sağlamak için en iyi yöntemdir. O yaştaki çocuklar 
oynayarak, yaparak yaşayarak öğrenmeye yatkındırlar. Oyunu yöntem olarak kullanmak çocuğun aktif hale gelmesini ve öğrenme konusunda daha kalıcı bilgiler edinmesini, hem de eğlendirici olarak yöntem olduğu bir görüşlerini savunmuşlardır.

\subsection{Oyunun Çocuğun Gelişimine Etkisi ve Önemi Hakkında Görüşler}

Öğretmen adayları, oyunun çocuğun gelişimi konusunda etkisi ve öneminin büyük olduğunu savunmuşlardır. Tüm gelişim alanlarına (fiziksel, zihinsel, psikomotor) etkisi vardır. $\mathrm{Bu}$ sebeple sosyalleşmelerine de oldukça etki ettiğini öngörmüşlerdir. Ayrıca duygusal açıdan da etki ettiğini ve oyunlarla çocukların duygularını özgürce ifade ettiklerini belirtmişlerdir. Dil gelişimini de tüm diğer alanları olduğu gibi etki ettiğini savunmuşlardır.

\section{3. Çocukların Evde ve Okulda Oyun Oynamadıkları Zamanları Nasıl Geçirdiklerine İlişkin Görüşler}

Ögretmen adayları bu konuda iletişim araçlarını en fazla örnek göstermişlerdir. Çocuklar evde ve okulda oyun oynamadıkları zamanları ya televizyon izleyerek ya da akıllı telefonlarla geçirmiş bu konuda da zihinselgelişimi ve yaratıcılıklarını olumsuz etkilediğini söylemektedirler.

\section{4. Çocukların Oyun Olarak Nitelendirmedikleri Faaliyetler}

Genelde çocukların oyun olarak nitelendirmekdikleri etkinlikler, aile ziyaretleri, alışveriş, gezmek veya çizgi film izlemek en başta sıraladıkları durumlar görünmüştür.

\section{5. Çocukların İş Olarak Nitelendirdikleri Faaliyetler}

Çocukların onlara verilen bir görevi yerine getirmeleri, odalarını toplamaları, ev işlerine yardım etmeleri kendi öz bakım ihtiyaçlarını yerine getirmeleri onların gözünden "iş" olarak nitelenmektedir. 


\subsection{Oyun Hangi Derslerde ve Hangi Amaçla Daha Fazla Kullanıldığı Konusundaki}

\section{Görüşler Nelerdir?}

Ogretmen adaylarının görüşlerine gore, bir dersi daha etkili bir şekilde anlatabilmek için oyunun kullanımı gerçekleşmektedir. Türkçe, drama ve müzik dersleri başta olmak üzere bütün derslerde kullanılabilir. Genelde ders sonuna doğru öğrencinin dersi daha iyi kavrayabilmesi için oyun oynanır. Ancak sürekli aynı oyunun herderste oynanmasının doğru olmadığını, sadece belirli derslerle ilişkilendirilmesi gerektiğini düşünmektedirler.

\section{7. Çocukların Kiminle Oyun Oynamayı Daha Çok Sevdiklerine Dair Görüşler}

\section{Nelerdir?}

$\mathrm{Bu}$ durum çocuktan çocuğa değişiklik gösterdiği bir gerçektir. Bireysel farklılıklar olduğu gibi bireysel gelişimlerinin ve ihtiyaçlarının çerçevesinde çocuklar oynamayı ihtiyaç olarak görebilir. Bu durumda bazı çocuklar kendinden yaşça büyüklerle, aileleriyle oynamak ister, bazıları da kendi yaşıtlarıyla oyun oynamaktan zevk alır. Bazı öğretmen adayına gore ise çocuğun en çok kendi başına oynadığı oyunlar en etkili eyunlarolarak nitelendirdikleri görülmektedir.

\section{SONUÇ VE ÖNERILER}

Araştırma sonucunda, okul öncesi öğretmen adaylarının çocukların gelişimleri açısından oyunu hem çocukla bir iletişim kaynağı gibi hemde çocukların vazgeçilmez bir işi olduğunun verdikleri cevaplar doğrultusunda farkında oldukları görülmüştür.

Okul öncesi öğretmenlerinin özellikle derslerde oyunun yoğun kullanımını desteklemekteler. Öğretmen adayları günümüzdeki akıllı telefonların oyun aracı olarak saymadıkları ve çocuğu oyundan çok bağımlılığa ittiği görüşündedirler.

Çocukların oyuna ilişkin algılarının büyük ölçüde öğretmenlerin tutum ve davranışlarından etkilendiği göz önünde bulundurulduğunda, öğretmenlerin oyunu diğer etkinlikler kadar ciddi bir şekilde ele alarak oyunların yoğunluğu ve niteliği arttırılmalıdır. Benzer şekilde aileler de çocukların oyununa değer veren tutum ve davranışlar sergilemeli ve bu konuda desteklenmelidir. Lisans bakımından da öğretmen adaylarının eğitim hayatlarında 
aldıkları derslerde oyunun önemi daha fazla belirtilmeli, yöntem olarak kullanılması öğretilmeli ve oyun hakkında öğretmen adaylarına daha kapsamlı bilgiler verilmelidir.

\section{Kaynakça}

Huizinga, J. (1955). Nature and significance of play as a cultural phenomenon.

Sluss, D. J. (2005). Supporting play: Birth through age eight. Wadsworth Publishing Company.

Kervan, S. (2020). Okulöncesi ve ilköğretimde yaratıcı drama ve oyun (Kosova Müfredatı Ders İşleniş Örnekleriyle). Prizren, Kosova. İSBN:978-9951-820-02-8

Koçyiğit, S., \& BAYDİLEK, N. B. (2015). Okul öncesi dönem çocuklarının oyun algılarının incelenmesi. Yüzüncü Yıl Üniversitesi Eğitim Fakültesi Dergisi, 12(1), 1-26.

Ayan, S., \& Memiş, U. A. (2012). Erken çocukluk döneminde oyun. Selçuk Üniversitesi Beden Eğitimi ve Spor Bilim Dergisi, 14(2), 143-149.

Tuğrul, B., Metin Aslan, Ö., Ertürk, H. G., \& Özen Altınkaynak, Ş. (2014). Anaokuluna devam eden altı yaşındaki çocuklar ile okul öncesi öğretmenlerinin oyun hakkındaki görüşlerinin incelenmesi.

Ulutaş, A. (2011). Okul öncesi dönemde drama ve oyunun önemi. Adlyaman Üniversitesi Sosyal Bilimler Enstitüsü Dergisi, (6), 232-242.

Koçyiğit, S., Tuğluk, M. N., \& Mehmet, K. Ö. K. (2007). Çocuğun gelişim sürecinde eğitsel bir etkinlik olarak oyun. Atatürk Üniversitesi Kazım Karabekir Eğitim Fakültesi Dergisi, (16), 324-342.

Erbil Kaya, Ö. M., Yalçin, V., Kimzan, İ., \& Avar, G. (2017). Okul Öncesi Öğretmeni Adaylarinin Oyun Temelli Öğrenmeye Bakiş Açilari Ve Uygulamaya Yansimalari*. Adiyaman Üniversitesi Sosyal Bilimler Enstitüsü Dergisi , 800-834.

Tok, E. (2017). Okul Öncesi Öğretmen Adaylarının Oyuna İlişkin Algıları: Metafor Analizi Örneği. Kastamonu Education Journal , 600-610. 